DOI: https://doi.org/10.3126/tgb.v6i0.26166

\title{
An Assessment of Disaster Loss and Damage in Nepal
}

\author{
Buddhi Raj Shrestha ${ }^{1}$
}

\begin{abstract}
A disaster is a natural or manmade hazard resulting in an event of substantial extent causing significant physical damage or destruction, loss of life or drastic change to the environment. Due to diverse geographical coverage, Nepal is prone to various geological and hydro-meteorological hazards. This paper tries to show the types of disaster, losses and damages induced by disaster and analyze the trend and geographical distribution of disaster in Nepal. This study is based on the secondary data sources. Disaste r events data were collected from NSET and other government research papers, library etc. 26,665 events were reported during a 45 year and 43,868 people were died, 2,828 people were missing by disaster. Fire, flood landslide, accident and thunderstorms are major disasters in terms of occurrences and Earthquake, flood, and landslide are the major disasters in terms of damages and losses. The trend of disaster events is gradually increasing from the 1971 to 2000 but after 2000 the trend of disaster is drastically increasing to 2016. Annually 593 disaster events have occurred in Nepal. The data of impacts caused by the disasters also reveal that the estimated annual economic loss is increasing with the increasing frequency of disasters. The number of natural disasters as well as the number of corresponding casualties, injured and affected people, and economic loss is steadily on the rise. Tarai and Hilly districts are highly vulnerable than Mountain districts and Hill and Tarai region are most affected than Mountain region due different disaster in Nepal. The Tarai and some central hill districts are most vulnerable in terms of disasters occurrences. Among the seven provinces, province no 3 recorded the highest number of human deaths and disasters occurrences.
\end{abstract}

Key words: Disaster, damages, losses, trend, environmental loss, distribution.

\section{Introduction}

Disaster brings the serious disruption of the functioning of a community or a society involving wide spreading human material economic or environmental losses and

${ }^{1}$ Geographer, Earthquake Safe Communities in Nepal (NSET). Corresponding e-mail: biraj323@gmail.com 
impacts which exceeds the ability of the affected community to cope using its own resources" (UNSIDR, 2009). A disaster is a natural or manmade hazard resulting in an event of substantial extent causing significant physical damage or destruction, loss of life or drastic change to the environment. A disaster can be defined as any tragic event stemming from events. More than 100 people dead or injured and more than 1 million US\$ in damages (Burton, Kates, \& White, 1978). "Hazard" represents potential events while "Disasters" result from actual events involving humans and what they value.

Nepal is a Himalayan country, lies in between $8004^{\prime}$ to $88^{\circ} 12^{\prime}$ East longitude and $26^{0} 22^{\prime}$ to $30027^{\prime}$ North latitude. It has an area of $147,181 \mathrm{sq}$. $\mathrm{km}$. extending roughly to $885 \mathrm{~km}$. from East to West and varies from 145- $241 \mathrm{~km}$. North-South. The country is landlocked bordering with India on the East, West and South, and China on the North. Nepal is situated in the middle portion of the Hindu Kush Himalayan $(\mathrm{HKH})$ Region (Figure 1). The altitude ranges from a minimum of about 60 meters to 8,848 meters. The climate varies with its topography and altitude. A combination of rugged topography, high relief, active tectonic process and intense monsoon rain have made this fragile environment vulnerable to different types of hazards and disasters. "The country stands at the top 20th list of the most multi-hazard prone countries in the world. The country is ranked 4th, 11th and 30th in terms of climate change, earthquake, and flood risk respectively." (UNDP/ BCPR, 2004). In addition, to flood, landslide and fire, the country is prone to earthquake as it is in the Himalayan Range where Tibetan and Indian Plates colliding each-other. Recently, thunderstorm and the epidemics have become those disasters that have been claiming numbers of human lives. 


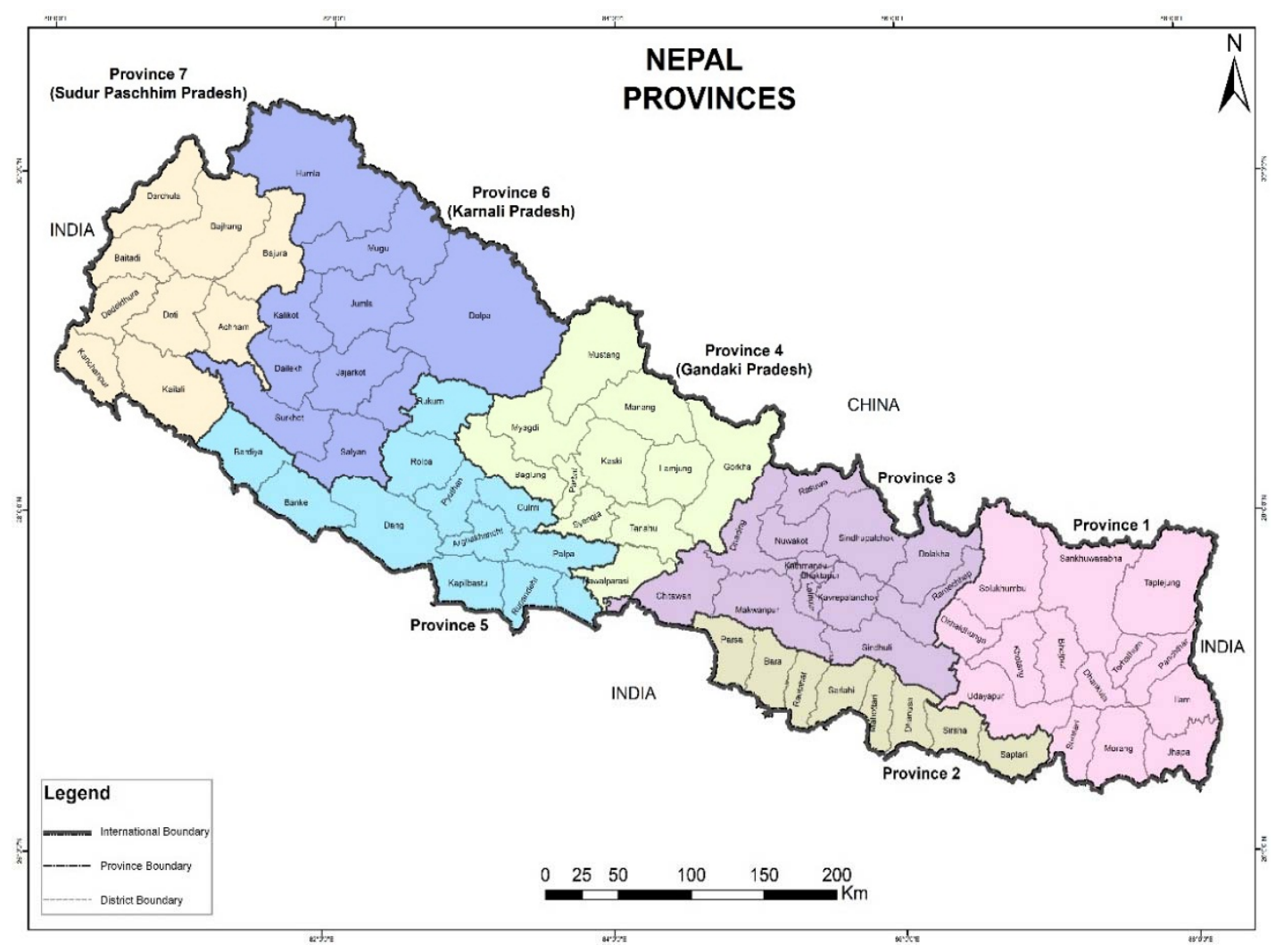

Figure 1 Location of study area

\section{Tools and techniques}

This study is based on the secondary data. No exact statistics are available on the loss of lives and property caused by historical disaster events. Few available records are only on the events with big impacts but thousands of small and medium size events are missing from the records.

In this context, the effort was carried out by the National Society for Earthquake Technology - Nepal (NSET) to establish a systematic data inventory of natural disaster events in Nepal. NSET has provided 45 years disaster data (1971-2016). Besides that, data from Minister of Home affairs Nepal and other available reports, relevant journals, articles etc. are collected. The data is analyzed is Microsoft Excel and it has further linked to GIS system for further analysis and mapping. 


\section{Results and discussion}

\section{Disaster profiles}

Table 1: Hazard profile

\begin{tabular}{|c|c|}
\hline Types of hazards & Prevalence \\
\hline \multicolumn{2}{|l|}{ Natural hazards } \\
\hline Earthquake & $\begin{array}{l}\text { All of Nepal is a high-hazard earthquake } \\
\text { zone }\end{array}$ \\
\hline Flood & Tarai (sheet flood), Middle Hills \\
\hline Landslide and landslide dam break & Hills, Mountains \\
\hline \multirow[b]{2}{*}{ Debris flow } & $\begin{array}{l}\text { Hills and Mountain, severe in areas of } \\
\text { elevations greater than }\end{array}$ \\
\hline & $\begin{array}{l}1700 \mathrm{~m} \text { that are covered by glacial deposits } \\
\text { of previous ice-age }\end{array}$ \\
\hline \multirow[b]{2}{*}{$\begin{array}{l}\text { Glacier lakes outburst floods } \\
\text { (GLOF) }\end{array}$} & $\begin{array}{l}\text { Origin at the tongue of glaciers in Higher } \\
\text { Himalayas, }\end{array}$ \\
\hline & $\begin{array}{l}\text { Higher Mountains, flow reach up to middle } \\
\text { Hill regions }\end{array}$ \\
\hline Avalanche & Higher Himalayas \\
\hline Fire (forest) & $\begin{array}{l}\text { Hills and Tarai (forest belt at foot of } \\
\text { southern-most Hills }\end{array}$ \\
\hline Drought & All over the country \\
\hline Storms/ Hailstorm & Hills \\
\hline \multicolumn{2}{|l|}{ Man-induced hazards } \\
\hline Epidemics & $\begin{array}{l}\text { Tarai and Hills, also in lower parts of } \\
\text { Mountain region }\end{array}$ \\
\hline Fire settlements & Mostly in Tarai, also in mid-Hill region \\
\hline Accidents & Urban areas, along road network \\
\hline Industrial/Technological hazards & Urban / industrial areas \\
\hline Soil erosion & Hill region \\
\hline Social Disruptions & $\begin{array}{l}\text { Follows disaster-affected areas and } \\
\text { politically disturbed areas }\end{array}$ \\
\hline
\end{tabular}

Source: NSET 2009 (adopted from Dixit, 1996).

Nepal is one of the vulnerable countries in the world due to its fragile landscape, climate sensitive ecosystem and socioeconomic circumstances. The 'Himalayan dilemma' (Ives \& Messerli, 1989) associated with the impacts of land-use changes has, hence, become more complex owing to the additional potential effects of global 
climatic change (Sharma, Charles, Berrien, 2000). The effects of environmental changes in high mountainous areas, such as the Himalayan region, have been drawing significant attention of the scientists in recent years. Additionally, Nepal is on the frontline of climate change with a wide array of climate and habitats varying from the freezing Himalayas of the north to the hot lowland plains of the south (ICIMOD, 2009).

The geological reasoning of Nepal being susceptible to a variety of natural hazards is confirmed by the real occurrence of disastrous events. Most frequent hazards are landslides, floods, epidemics, fires, earthquake and other hydro-meteorological disasters (heavy rain, thunderstorm, hailstorm, windstorm etc.), causing heavy loss of human lives as well as economic loss including housing and infrastructures. For example, the 1934 Bihar-Nepal Earthquake (M8.3), the 1988 Udaypur Earthquake (M6.6) and the 2015 Gorkha Earthquake (M7.6) were the most devastating

earthquakes in Nepal during last 80 years. Jure landslide of 2014 and the 1993 floods in south-central Nepal resulted in huge loss of lives and properties including housing and other infrastructures (roads, hydropower, and electricity). The economic cost associated with natural disasters has increased tremendously. Fire, drought and epidemics are also prevalent in Tarai region. The Hill region, including the Siwaliks (or the Churia Range) experiences landslide, debris flow along creeks along steep slopes, floods in the lower stages of river terraces and erosion along the river banks during monsoon period. The higher Mountain region is exposed to rock and snow avalanches, rock slides, and debris flows.

The trend of human death and events in 45 years' time from 1971-2016 is shown in figure 2. This trend line of the human death shows that there are a low number of human deaths with low disaster events in the beginning of the 1970s and 1980s. But after 1990s the number of human death and disaster events are highly increasing to 2004 and it is going down in 2005. After that again the trend line is drastically increased to 2015 and down in 2016. It shows that the number of human death and events are increasing annually. 


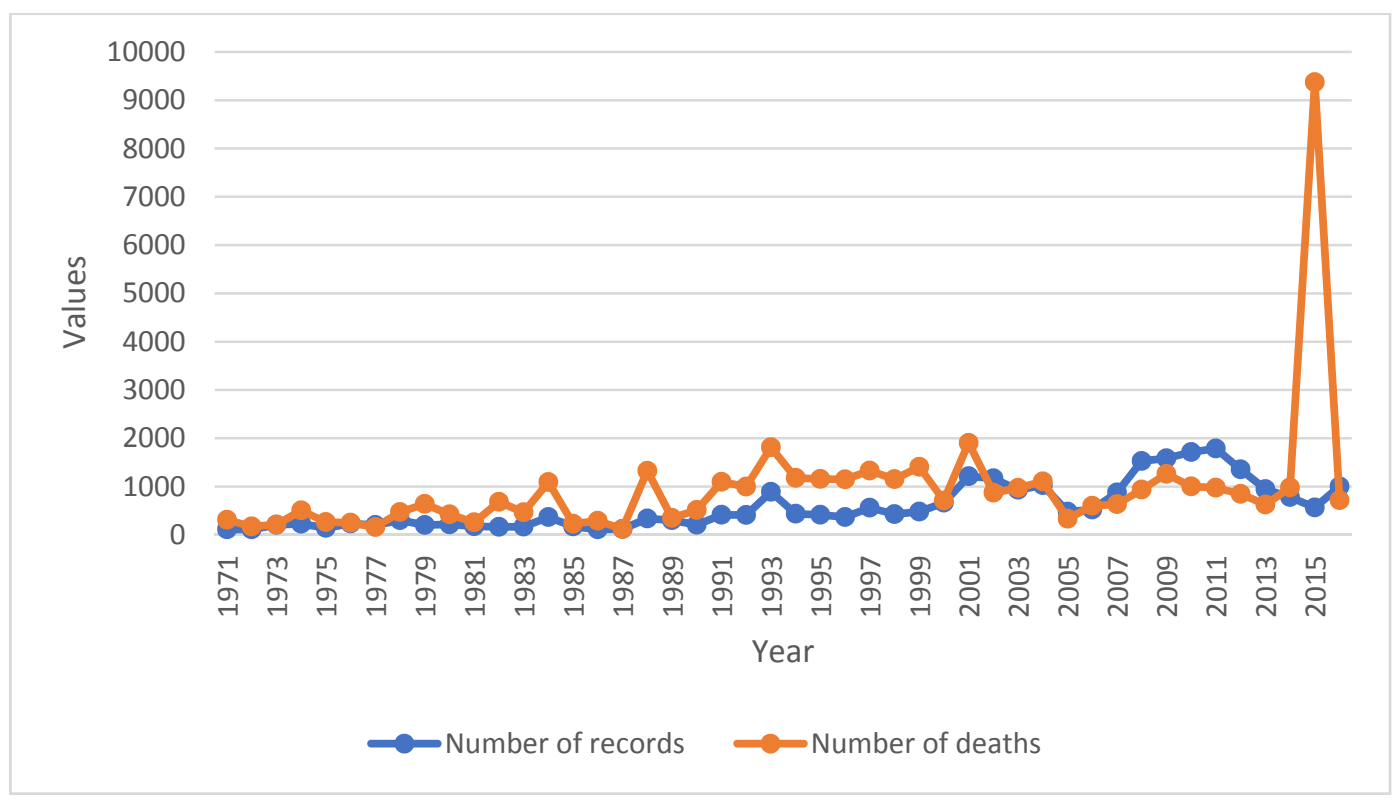

Figure 2 Trend of disaster

\section{Disaster occurrences, losses and damages}

The data between 1971 to 2016 reveals that fire, flood and landslide claim 54\% 13\% by epidemic, $1 \%$ by earthquake and remaining $32 \%$ events are claimed by strong wind, structural collapse, cold wave, plague and other events (Figure 3).

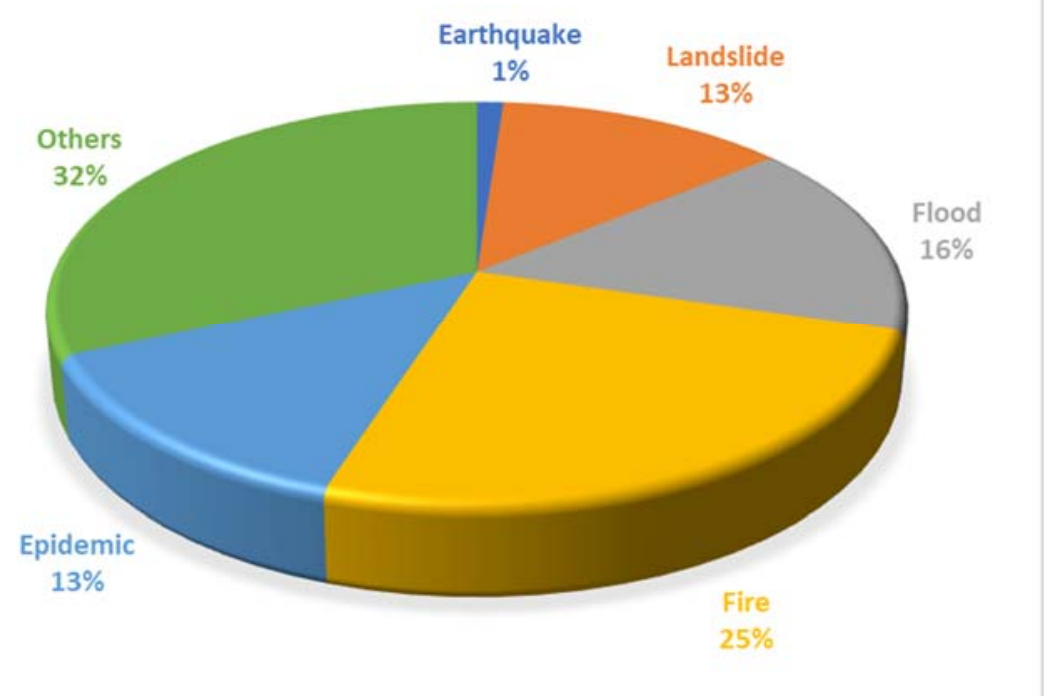

Figure 3 Disaster composition 


\section{Damages and losses by disaster}

Epidemics, landslides, floods, fire, thunderstorm, accident, and earthquake are some of the common hazards in Nepal. They contribute significantly to the total annual loss of life and damage to property in Nepal. Nepal is witnessing increasing numbers of casualties and damages due to various types of natural and human induced disasters many human beings have been died, injured and missing due to different disasters. Similarly, livestock, infrastructure, agricultural land was also have lost by disaster in Nepal. The database for 1971-2007 reveals that flood, fire and epidemics are major disasters in terms of number of disaster records whereas epidemic, landslides and floods are major disasters in terms of deaths due to natural disasters (NSET, 2007). The database for the period of 1971-2016 also reveals that Epidemic, Earthquake, landslide and flood are major disaster in terms of damages and losses whereas Fire, flood and epidemic are major disaster records in terms of number of disasters. The number of deaths summed up to 43,868 yearly averages of 993 and similarly 83,384 people were injured due to different disaster and 2,828 people are still missing. Besides that, the high numbers of population totaling of 79,61,992 people were affected by disaster and 8,45,947 houses were destroyed.

Most of the people were killed and injured by epidemic, earthquake, landslide, fire, accident and flood respectively. A total of 16,795 people has lost their lives due to epidemic followed by Earthquake that claimed 9,718. Landslide killed 5,157 people, 3891flood, 1491 by fire and various other disasters killed 1,299 people. In this way altogether 43,824 people have died since 1971 to 2016 in Nepal. Similarly, 83,384. people were injured by disasters among that 43,076 people have injured by epidemic, 29,360 by earthquake, 3,123 by thunderstorms. A total of 2,842 people was missing by different disasters and the highest numbers of people were missing by flood that is 1,020 and followed by landslide 747 people, accident 320 people and 722 people were missing by other disaster. Earthquake is the major causes for the huge ecomomic losses which is 70,60,580 million, 28,843 million by fire,6,113 million by flood, and 1,393 million by landslide and 12,253.89 million rupese lost by other disasters (Table 2).

Table 2 Damages and losses by disaster

\begin{tabular}{|l|r|r|r|r|r|}
\hline \multicolumn{1}{|c|}{ Events } & Data cards & Death & Injured people & Affected people & Loss million \\
\hline Earthquake & 310 & 9,718 & 29,360 & $9,33,231$ & $70,60,580.8$ \\
\hline Landslide & 3,421 & 5,190 & 1,925 & $6,07,091$ & $1,393.5995$ \\
\hline Flood & 4,166 & 3,902 & 571 & $46,00,580$ & $6,123.3941$ \\
\hline
\end{tabular}




\begin{tabular}{|l|r|r|r|r|l|} 
Fire & 6,766 & 1,491 & 1,699 & $3,13,816$ & $28,843.955$ \\
\hline Epidemic & 3,573 & 16,795 & 43,076 & $5,21,449$ & 2.63104 \\
\hline Others & 8,429 & 6,772 & 6,753 & $10,23,467$ & $7,343.424882$ \\
\hline Grand Total & 26,665 & 43,868 & 83,384 & $79,99,634$ & $71,04,287.805$ \\
\hline
\end{tabular}

Source:Nepal desinventar database, 2016.

Gorkha Earthquake 2015: Over the last 80 years, another high Richter scale earthquake (7.6) on 25 April, 2015 and its aftershocks have been the terrible calamity in Nepal as they affected more than one third area of the country (NPC, 2015). It is estimated that nearly 9,000 people lost their lives and more than 22,000 people were injured. As per the latest estimates, more than half a million houses are damaged. It is estimated that the lives of eight million people, almost one-third of the population of Nepal, have been impacted by the earthquake (NPC, 2015). The scale of destruction is immense.

\begin{tabular}{|c|c|c|c|c|c|c|c|c|c|c|c|c|}
\hline Provinces & Event & $\%$ & Death & $\%$ & Missing & $\%$ & Injured & $\%$ & $\begin{array}{l}\text { Destroyed } \\
\text { house }\end{array}$ & $\%$ & $\begin{array}{l}\text { Affected } \\
\text { people }\end{array}$ & $\%$ \\
\hline 1 & 5,646 & 21 & 5,578 & 13 & 551 & 19 & 15,016 & 18 & 88,393 & 10 & $9,31,696$ & 12 \\
\hline 2 & 4,373 & 16 & 5,363 & 12 & 288 & 10 & 9,296 & 11 & 90,139 & 11 & $31,28,830$ & 39 \\
\hline 3 & 5,820 & 22 & 14,694 & 33 & 599 & 21 & 34,469 & 41 & $5,03,229$ & 59 & $13,84,987$ & 17 \\
\hline Gandaki & 3,373 & 13 & 4,025 & 9 & 473 & 17 & 5,595 & 7 & $1,01,038$ & 12 & $10,61,501$ & 13 \\
\hline 5 & 3,044 & 11 & 4,518 & 10 & 456 & 16 & 5,964 & 7 & 37,110 & 4 & $5,18,149$ & 6 \\
\hline Karnali & 2,097 & 8 & 4,901 & 11 & 270 & 10 & 2,249 & 3 & 5,072 & 1 & $4,45,989$ & 6 \\
\hline $\begin{array}{c}\text { Sudur } \\
\text { Pachhim }\end{array}$ & 2,312 & 9 & 4,789 & 11 & 205 & 7 & 10,795 & 13 & 22323 & 3 & 528482 & 7 \\
\hline Total & 26,665 & 100 & 43,868 & 100 & 2,842 & 100 & 83,384 & 100 & 847304 & 100 & $79,99,634$ & 100 \\
\hline
\end{tabular}

Analysis by provincial region

Table 3 shows the disaster events,damages and losses in seven provinces in Nepal. The distribution of disaster occurrences, damages and losses are differenti in different province. In terms of disaster events province 3 has highest numbers that is 5,646 events with highest human death (33\%). After that Province 1 is second position in terms of disater events and human death followed by provinc $2,4,5,7$ and 6 respectively.Comparatively province5, 6 and 7 have low number of disastrer 
events, damages and losses. A total of 79,99,634 people were affected by different disaster during 45 years. Among that $39 \%$ people were affected in province 2 .

\section{Conclusion}

Different types of hazards are common and frequently taking place in Nepal. From 1971-2016 altogether 26,665 events and 43,865 human deaths have been recorded in Nepal. Epidemic, Earthquake, landslide and flood are found the major disasters in terms of occurrences and human fatalities.

The trend of disaster events has been gradually increasing from the 1971 to 2000 but after 2000 it has been rapid until 2016. Altogether 16,795 people died by epidemic, 9,718 people by earthquake,9,092 died by landslide and flood and 6,772 died by other disaster from1971-2016 in Nepal. In the regional context, province no 3 and 1 have the more vulnerable in terms of disaster occurrences and human death. Province 4,5,6 and 7 are comparatively lower disaster occurrences, human death compared to other provinces.

\section{Reference}

Burton, I., Kates, R.W., White, G.F., 1978. The environment as hazard. Guilford, New York.

International Centre for Integrated Mountain Development (2009): Local responses to too much and too little water in the greater Himalayan Region. International Center for Integrated Mountain Development (ICIMOD), Kathmandu, Nepal, 76p.

Ives I. D., Messerli B. (1989): The Himalayan dilemma, reconciling development and conservation, Routledge, London, p. 295.

National Planning Commission (2015): Nepal Earthquake 2015, Post disaster needs assessment, Vol. A: Key Findings. National Planning Commission, Government of Nepal, Kathmandu, Nepal

NSET. (2007). Disasters in Nepal: Inventory of events and analysis of impacts (Period covered 1971-2006), Preliminary Analysis (In-house unpublished report under the DesInventar Project of NSET). National Society for Earthquake TechnologyNepal, Kathmandu.

National Society for Earthquake Technology - Nepal (NSET) 2009, Global assessment of risk, Nepal country report, Submitted to ISDR Global Assessment Report on Poverty and Disaster Risk 2009 Submitted by NSET. 
NSET. (2016). In-house printing: Disaster in Nepal: Inventory of events and analysis of impacts 1971-2016. Lalitpur.

UNDP/BCPR (2004), A global report reducing disaster risk-a challenge for development, United Nations Development Program, Bureau for crisis Prevention and Recovery, Geneva.

UNISDR (United Nations International Strategy for Disaster Reduction). (2009). UNISDR Terminology on disaster risk reduction. Geneva: UNISDR. http://www.desinventar.net/DesInventar/main.jsp?countrycode=npl 